\title{
FROM THE EDITOR
}

Polonia Journal Issue number 10 has been devoted to the topic of MIGRATION in a wide-ranging sense. Migration in the real time and imagined time, in geographic and psychological spaces, experienced by migrants in search of a better life and peaceful living conditions for their loved ones.

In this Polonia Journal issue, essay authors describe the fate of legal and illegal migrants, people consciously and voluntarily leaving their places of residence or the migrants who are forced to leave by political events or by drastic changes in their standard of living. The authors cover the topics which today have become fodder for communication media in a general sense, for science and art. Migration movements have sparked the imagination of artists and the inquisitiveness of research people.

How to analyze the topic of migration, which emotionally engages people, in the most objective way, if not through intellectual distance offered by art on the one hand, and insightful and meticulous fact analysis referring to types of migration, on the other? We have gathered nine essays in this issue, the authors of which analyse the phenomenon of migration in the chosen literary, drama and film works and present real facts and events illustrating their theses. It is our opinion that such a grouping of texts illustrates the complexity of migration phenomena in a most thought-provoking way.

The first essay "Migrations and Mirages" written by Paul Coates treats about the relation between the desire to migrate and the lure of the distance. The latter may be a mirage in the sense of an illusion but it may also exist for real, similar to a mirage in the desert beyond the horizon, despite the fact that the horizon constantly moves. This essay 
is full of literary and film references to the ideas of migration, horizon, invisibility, Islam, Catholicism while it draws from literary and film works by Mariève Rugo, Jenny Erpenbeck and Roberto Rossellini.

Alicja Helman in her essay "Migrations of Aliens. The Topic of Migration in The Spectacle by Adriane Mnouchine" analyzes and interprets Ariane Mnouchine's 2006 film based on her own theatrical piece of 2003 „Le Derniere Caravansérail (Odyssées)”. The play focuses on the problem of migration from the perspective of individual experiences of people as told by themselves in camps in Sangatte, Lombok, and Villawood. The author of the essay describes real experiences of the emigrants which Ariane Mnouchine portrays in the spectacle and then in the film based on her spectacle.

In "Hester Street: Living Between Worlds", Andrzej Piskorz concentrates on a novel about experiences of Jewish immigrants in America and on a film based on the novel. He focuses on the analysis of language which in the new reality bridges the old and the new, tradition and modernity, habits created in the homeland left behind and fresh possibilities offered by the New World. The paper discusses the film as a profound and multilayered meditation on the "production of identity" as a fluid, subjective and incomplete process.

In "Notes from Exile. "Skibet. Hatikvah" (1970/2010) and "Return to Poland” (1981) by Marian Marzyński, Joanna Preizner presents another analysis of the Jewish query. She studies Marzynski's film, the important motif of which is migration. Marzynski had to emigrate himself after "March '68" events and turned his experience into artistic works. His foreign debut „Skibet/Hatikvah” (1970/2010) made for Danish television is the first film record of the situation in which Poles of Jewish origin found themselves due to the antisemitic persecution.

In the essay "Cosmopolitanism, Migration in View of Krzysztof Kieslowski's Idealism" Janina Falkowska explores the idea of cosmopolitanism in the context of Krzysztof Kieslowski’s last films. She takes into consideration the idealistic tradition of cosmopolitanism and its later "degeneration" in the direction of the colonialist perspective; 
the author analyzes the film Bialy (White) which reveals internal contradictions and ambiguities in its idealistic approach to the ideas of cosmopolitanism and equality.

„To the West and Back. Migrations in Polish Cinema During the Transformation Period" is an essay written by Ilona Copik about the migration of Poles (leaving Poland and returning after many years) as portrayed in Polish cinema after 1989. She analyzes motifs accompanying such a migration in view of its many variants (political, economic and socio-civilizational). One of the most interesting elements of this essay is pursuing links between film, a real cultural space, and, a singular experience and identity.

Grzegorz Bubak in the essay "Migrations and Culture in Hungarian Films Made After the Fall of Communism" presents the influence of migrations on Hungarian culture, Hungarian society while he observes the behavior of Hungarian nationals towards outsiders, newcomers and representatives of other nationalities.

In „14 Kilometres to paradise. Images of Migration to Andalusia in Spanish Cinema", Joanna Aleksandrowicz discusses two approaches to the topic of migration depending on the geographic point of view. The film she discusses in her essay represents two perspectives: one is the point of view of Andalusians and Spaniards travelling South, and the other that of the migrants who reveal the essence of inter-cultural encounters from their own point of view.

The essay "Economic Relations Between Poland And New Zealand: Current State of Trade and Perspectives for Further Cooperation in Connection with The Increasing Migration of Poles" by Joanna Siekiera is an attempt to illustrate contemporary economic relations between Poland and New Zealand, as well as the anticipated development of this cooperation in the future. The main factor enabling the business organizations and enterprises operation between such far-away countries is indeed the increased migration of Poles. She devotes a lot of attention to the economic, sociological and political factors of Poles' migration to New Zealand over many years. Finally, she draws 
the readers' attention to the need of maintaining national links in New Zealand Polish community and to the great prospects of the future development of relations between Polonia and its home country.

The above essays cover only some topics in a huge research area of migration studies. Whole new research sub-areas, both theoretical and practical, dealing with this issue have emerged since the beginning of 1980s. Today migration is analyzed in the geographical spectrum (where to and why migrants move to a particular location); in the political spectrum (why specific political events prompt people to leave their country); in the economic view (how economic worries influence migrants' decision to move); in the psychological aspect (what psychological influence migration has on the mental well-being of a migrant), and many other facets.

As a film theoretician and cultural theory research person, I consider migration representation in art the most important factor allowing for understanding of the destructive and constructive aspects of migration movements, and, for accepting complex ambiguities in an effort to interpret the phenomenon of migration in its entirety. Undoubtedly, the essays brought by this issue of Polonia Journal contribute to the feelings of both dismay and euphoria which accompany our thoughts about migration, interpreted as a painful and creative phenomenon at the same time.

Prof. Janina Falkowska 